\title{
Bovine Claw and Limb Disorders at Claw Trimming Related to Milk Yield
}

\author{
Å. M. Sogstad, ${ }^{*} \dagger^{1}$ O. Østerås, ${ }^{*} \dagger$ T. Fjeldaas, ${ }^{*}$ and A. O. Refsdalł \\ ${ }^{*}$ Department of Production Animal Clinical Sciences, Norwegian School of Veterinary Science, 0033 Oslo, Norway \\ †TINE BA, Department of Cattle Health Services, 1431 Ås, Norway \\ ‡GENO Breeding and A.I. Association, 2326 Hamar, Norway
}

\begin{abstract}
As part of a cross-sectional study of Norwegian Red Cattle, associations of lameness, lesions at the tarsus, claw shapes, claw lesions, and claw trimming with milk yield were examined. Fifty-five tie-stall herds and 57 free-stall herds were sampled by computerized systematic selection, and 2,665 cows were trimmed and limb and claw disorders recorded. After exclusions, 2,599 cows were included in this study. Monthly recordings of milk were extracted from the Norwegian Dairy Herd Recording System. Most claw lesions were mild (score 1). The prevalence of moderate and severe lesions (score 2 and 3) did not exceed $5 \%$ for any of the lesions. Associations with test-day milk yield were identified using regression analyses (Proc Mixed) with repeated measurements within lactation and herd as random effect. Lactation curves were fit to visualize differences in changes in milk yield throughout the lactation. Milk yield was generally higher in cows with lesions at the tarsus, heel-horn erosions, and hemorrhages of the white line and the sole than in cows without these lesions, whereas cows with dermatitis yielded less than cows without dermatitis. Cows in lactation 1 with corkscrewed claws had reduced milk yield, whereas cows in lactations 2 and above had increased milk yield compared with cows without corkscrewed claws in respective lactations. Cows in lactation 1 yielded $0.47 \pm 0.15 \mathrm{~kg}$ and cows in later lactations yielded $0.51 \pm 0.15 \mathrm{~kg}$ more milk on test days after claw trimming than they did before when adjusted for days in milk. In this study, where most disorders were mild, the most evident results were higher milk yield in cows with lesions at the tarsus, heel-horn erosions, and hemorrhages of the white line and the sole than in cows without these lesions. Cows yielded more milk after claw trimming than they did before trimming.
\end{abstract}

Key words: claw disorder, limb disorder, claw trimming, milk yield

Received June 22, 2006.

Accepted August 23, 2006.

${ }^{1}$ Corresponding author: aase.sogstad@veths.no

\section{INTRODUCTION}

Lameness causes reduced animal welfare and is among the 3 most loss-making diseases in the dairy industry after mastitis and fertility problems (Kossaibati and Esslemont, 1997). Losses in milk yield and protein and fat content of the milk are among the main factors contributing to economic losses (Enting et al., 1997).

Milk is produced at the cost of other metabolic processes in the body and high milk yield has been associated with lameness and claw lesions by Alban et al. (1996) and Hultgren et al. (2004). A Danish study found that the relationship between milk yield and sole ulcers was dependent on BW and lactation number (Enevoldsen et al., 1991a). Lameness has also been associated with a decrease in milk yield (Rajala-Schultz et al., 1999; Warnick et al., 2001; Hernandez et al., 2005). The average Norwegian Red Cow (NRF) yields 6,541 kg per year (TINE Rådgivning, http://org.tine.no). The NRF has much higher capacity and this relatively low yield is the result of price mechanisms and feeding regimens. Fleischer et al. (2001) showed that the probability of claw diseases increased almost proportionally with milk yield from an annual yield of $6,000 \mathrm{~kg}$. Probably, a high milk yield increases the risk of lameness and claw lesions, whereas a lameness incident decreases the milk production temporarily (Fourichon et al., 1999). Rajala-Schultz et al. (1999) found that the decline in milk yield started up to $2 \mathrm{wk}$ before lameness was diagnosed. Green et al. (2002) found that the decrease in milk yield after a lameness episode persisted for 4 mo. They concluded that some of the potential of high-yielding cows might be lost if they became lame. In contrast, there are studies in which no relationship between average milk yield and lameness has been revealed (Aeberhard et al., 2001). Gröhn et al. (1995) claimed that high-yielding cows are not necessarily more susceptible to disease as long as husbandry and nutrition meet their increased biological needs.

Lactation curves enable surveillance of milk production throughout the lactation and detection of exact times of decreases in milk yield. The aim of this paper was to detect associations of lameness, lesions at the tarsus, claw shapes, and different scores of claw lesions 
with milk yield. Milk yield before and after claw trimming was assessed.

\section{MATERIALS AND METHODS}

\section{Selection Procedure}

Herds were stratified based on the 3 most animaldense regions of Norway. Approximately 500 herds with $\geq 15$ cows were sampled by computerized systematic assignment from each region by using the Norwegian Dairy Herd Recording System (NDHRS). This study was part of a claw health project using Norwegian cattle in which the main aim was to compare claw health of cows housed in tie-stalls and free-stalls. In region 1 , 91 herds had free-stalls and every third of these was included. In region 2 , only 25 had free-stalls and all were included. In region 3, 84 herds had free-stalls and every third of these was included. One tie-stall for every free-stall was randomly sampled. After negative responses, exclusions, and dropouts, 55 tie-stalls and 57 free-stalls were included. Claw lesions of cows and heifers more than 18 mo of age and of the Norwegian Red cattle breed were recorded. Only females that had calved or were less than $30 \mathrm{~d}$ from first calving were included in this study.

\section{Study Population}

Average (mean \pm SD) number of cows per herd was $25 \pm 10$ and milk production per cow per year was 6,286 $\pm 844 \mathrm{~kg}$. Approximately $37 \%$ of the energy in the diet came from concentrates, $40 \%$ from grass-silage, $18 \%$ from grass at pasture, and the remainder from other sources. Feeding, housing, and management are described elsewhere in more detail (Sogstad et al., 2005a,b).

Prevalence of lameness and claw lesions in hind claws was $1.2 \%$ lameness, $26.4 \%$ heel-horn erosions, $16.3 \%$ sole hemorrhages, $10.9 \%$ white-line hemorrhages, $2.8 \%$ sole ulcers, and $7.8 \%$ white-line fissures (Sogstad et al., 2005a, 2006). Most lesions were mild. Prevalence of moderate and severe lesions did not exceed 5\% for any of the lesion categories.

The original study population contained 2,665 cows. The observation period was the lactation when the claw trimming was performed or the lactation starting with calving at most $15 \mathrm{~d}$ after claw trimming. Calving date, lactation number, culling date, or subsequent calving date and test-day milk yield in kilograms (monthly testing) was extracted from the NDHRS. There were 22,432 test-day observations. Test days within $6 \mathrm{~d}$ after calving and test-day observations $<5 \mathrm{~kg}$ of milk were excluded. Eight cows were excluded because of missing calving dates and 58 cows because of no available test-day milk yield recordings, resulting in a final study population of 2,599 cows.

\section{Recording of Data}

Fourteen professional claw trimmers (exclusion of 1 resulted in a total of 13 claw trimmers) attended 2 courses covering claw trimming procedures, diagnosis, recording, and treatment of claw lesions. Individual training was given to each claw trimmer at the initiation of the practical work. The cows were trimmed and examined once during the period from January 1, 2002, until cows were turned out to pasture during summer. The last herd was visited on June 28.

At claw trimming, the median lactation stage in first parity was 152 DIM; $25 \%$ of the cows were before 77 DIM and $25 \%$ were later than 229 DIM. In later parities, the median was 146 DIM; $25 \%$ of the cows were before 73 DIM and $25 \%$ were after 220 DIM.

Presence (1) or absence (0) of lameness was assessed when the cow was moved to the trimming chute (Table 1). Peritarsal swellings and wounds were recorded as absent (0), swelling (1), wounded (2), or both swelling and wounded (3). Claw shapes were recorded as normal (0), asymmetric (1), or corkscrewed (2). Asymmetric hind claws were characterized by a particularly large outer claw with a normal or outward-bent abaxial wall and a small inner claw. Corkscrewed hind claws included both mild cases in which the abaxial wall of the outer claw was bent inwards with a curved dorsal border and serious cases of corkscrew claws in which the abaxial wall was part of the weight-bearing surface. Claw lesions were diagnosed on the basis of macroscopic examination before and after trimming to the correct claw shape. Trimming technique included leveling the 2 claws, aiming for symmetric bulbs. The axial and abaxial walls were both intended to be parts of the bearing surface and the 2 claws were trimmed flat and balanced with each other. The caudal two-thirds of the axial sole of both claws were sloped toward the interdigital space. Dermatitis, heel-horn erosions, hemorrhages of the white line, and the sole, sole ulcers, and whiteline fissures were scored as absent (0), mild (1), moderate (2), or severe (3). Definitions in Table 1 were adapted from Bergsten (2000).

\section{Statistical Analysis}

The information recorded at the farm was transferred to SAS version 9.1 (SAS Institute Inc., Cary, NC) for statistical analyses. Lameness and all claw lesions occurred at a higher frequency in hind claws than in front claws and analyses were performed only in hind claws. To parameterize the lactation curve, a modification of 
Table 1. Definitions of lameness and claw lesions recorded at trimming

\begin{tabular}{|c|c|c|}
\hline Lesion & Score & Definition \\
\hline Heel-horn erosion & $\begin{array}{l}1 \\
2 \\
3\end{array}$ & $\begin{array}{l}\text { Slight defects of the horn integrity, pits and small fissures } \\
\text { V-shaped fissures or craters of the heel/bulb not affecting corium } \\
\text { V-shaped profound fissures or craters affecting corium of the heel/bulb }\end{array}$ \\
\hline Hemorrhages of the sole & $\begin{array}{l}1 \\
2\end{array}$ & $\begin{array}{l}\text { Slight hemorrhagic discoloration } \\
\text { Moderate hemorrhage on a single spot or several superficial hemorrhages covering }>20 \% \\
\text { of the sole surface } \\
\text { Profound hemorrhage on a single spot or extensive hemorrhagic discoloration covering }>50 \% \\
\text { of the sole }\end{array}$ \\
\hline White-line fissure & $\begin{array}{l}1 \\
2 \\
3\end{array}$ & $\begin{array}{l}\text { Fissure that disappears with deep cut beneath normal trimming level } \\
\text { Deep fissure perforating next to the corium of sole or wall } \\
\text { Corium is affected with purulent exudates, eventually with necrosis, granulation tissue, } \\
\text { and separation of the wall or sole }\end{array}$ \\
\hline
\end{tabular}

the Wood (1967) lactation curve (Wood, 1967; Schaeffer et al., 2000; Macciotta et al., 2005) was used. This method combines the exponential and linear models proposed by Wilmink (1987) and gave a better fit for our data than the Wood curve. The model was fit using Proc Mixed with repeated monthly observations of testday milk yield within lactation applying an autoregressive (1) covariance structure. Herd was also included as a random effect. The general equation for all models in this study was

$$
\begin{aligned}
Y_{i j k}=a_{i j k} & +b_{1 i j k} D M_{i j k}+b_{2 i j k} \operatorname{lnDIM} M_{i j k} \\
& +Z_{j k g},+Z_{k g}+e
\end{aligned}
$$

where $Y_{i j k}=$ daily milk yield at test-day i for lactation $\mathrm{j}$ in herd $\mathrm{k} ; \mathrm{a}_{\mathrm{ijk}}=$ intercept, $\mathrm{b}_{1 \mathrm{ijk}} \times \mathrm{DIM}_{\mathrm{ijk}}=$ the association with test-day $i$ at DIM in lactation $\mathrm{j}$ and herd $\mathrm{k}$; $\mathrm{b}_{2 \mathrm{ijk}}$ $\operatorname{lnDIM}_{\mathrm{ijk}}=$ the corresponding association of natural log of DIM; $Z_{j k} \gamma$ equals the random effect of lactation $j$ in herd $\mathrm{k} ; \mathrm{Z}_{\mathrm{k}} \gamma=$ the random effect in herd $\mathrm{k}$, and $\mathrm{e}=$ the random variation expected to have a mean of 0 and variance $\sigma^{2}$.

To evaluate the associations of lameness, lesions at the tarsus, claw shape, and different scores of claw lesions with milk yield, each of these variables was included one by one separately as additional covariates in equation 1 . The fixed variable was first included with all scores $(0,1,2$, and 3$)$. Nonsignificant scores having larger values than the significant one were grouped with the one of significance, preferably combining scores 2 and 3 . If none of the scores was significant, the variable was classified 0 and 1 (score 1,2 , and 3 ). In this way, we were able to evaluate not only possible associations of the lesions being present or not, but also possible cutoff points of subclinical lesions and severity of scores. To identify any association to the shape of the lactation curve, the interaction of the covariates and DIM as well as InDIM of test day was introduced one by one into equation 1 . Finally, a model with all significant covariates from the screening models was constructed.

To adjust for any seasonal effects on milk yield, the sine and cosine of the test-day number were introduced according to equations 2 and 3 as in Schukken et al. (1992) and Østerås et al. (2006):

$$
\begin{aligned}
& \text { sine }(\text { test day })=\sin [2 \times \pi \times(\text { test day/365) }) \\
& \text { cosine }(\text { test day })=\cos [2 \times \pi \times(\text { test day/365) })
\end{aligned}
$$

However, when comparing this method of including seasonal fixed effects with a method of including testday month by -2 log likelihood, the latter gave a better fit and was preferred.

A variable describing if the cow was diseased or not ( 1 or 0 ) on test day was introduced in addition to tie- 
stall (1) or free-stall (2). Number of days from claw trimming to test day was introduced to reveal any association between claw trimming and decreased or increased milk yield. This variable was transformed to a class variable defined as test day before trimming (1), within 1 mo after trimming (0), and more than $1 \mathrm{mo}$ after trimming $(-1)$. Amount $(\mathrm{kg})$ of concentrate fed on test day was tested in the models, but because of the collinearity of this variable to DIM, we decided not to include it. The full model was constructed by removing variables with $P<0.1$ one by one by a backward elimination procedure. The final model fit was assessed by -2 log likelihood.

When estimating milk yield for each claw lesion, the yield was adjusted for all other covariates in the model. By including claw and limb disorders with $P<0.1$ in the models, the results were adjusted to all other lesions with $P<0.1$ (except the one in question) being absent.

Separate models were run for first lactation and later lactations. In the model for later lactations, lactation number (second or third and higher) and the interaction between lactation number and DIM and InDIM were included.

The final model results were used to estimate and visualize the lactation daily milk yield (Figures 1 to 3 ) for each claw lesion, with yield adjusted for all other covariates in the model. The estimates were adjusted to the situation of free-stall housing, cows being healthy on test day, test day in May, test day before claw trimming, and all other lesions than the one in question being absent.

\section{RESULTS}

Associations between claw and limb disorders and milk yield at test day adjusted for DIM revealed from the mixed models in parity 1 and parity $\geq 2$ are in Tables 2 and 3. Lactation curves for cows with disorders that were associated with milk yield are in Figures 1 and 2. As expected, lactation curves were different in tiestalls and free-stalls (Figure 3). The estimated 305-d milk yield in first-lactation cows was $6,033 \mathrm{~kg}$ for a cow with lesions of the tarsus; $5,498 \mathrm{~kg}$ for a cow with corkscrewed claws; $5,697 \mathrm{~kg}$ for a cow with heel-horn erosions; $6,195 \mathrm{~kg}$ for a cow with hemorrhages of the white line; $5,689 \mathrm{~kg}$ for a cow with hemorrhages of the sole; and 5,636 kg for a reference cow. In later parities, the 305-d lactation milk yield was 7,457 $\mathrm{kg}$ for a cow with corkscrewed claw; $7,154 \mathrm{~kg}$ for a cow with dermatitis; $7,285 \mathrm{~kg}$ for a cow with hemorrhages of the white line; 7,463 kg for a cow with hemorrhages of the sole; and $7,218 \mathrm{~kg}$ for a reference cow. The test-day milk yield after claw trimming increased by $0.47 \pm 0.15 \mathrm{~kg}$ in first-lactation cows and by $0.51 \pm 0.15 \mathrm{~kg}$ in later lactations compared with before trimming when adjusted for DIM. The increase was already evident in the first month after claw trimming.

Lameness, sole ulcers, and white-line fissures were not associated with milk yield.

\section{DISCUSSION}

\section{General Discussion}

The shape of the lactation curve is influenced by herd factors such as management and nutrition and individual factors like genetics, parity, and disease. Discrepancies in the literature with regard to the effect of lameness and claw lesions on milk yield are partly the result of these complex influences.

The lactation curve can be parameterized by different mathematical models, as recently evaluated by Macciotta et al. (2004). By assessing the models of Wood (1967) and Wilmink (1987), we found that the Wilmink adjustment gave the best fit in our preliminary models before adding any fixed effects of claw lesions. Lactation 1 was run separately because the lactation curve in lactation 1 has a different shape from later lactations. Cows in lactation 1 are still growing and the relationship between milk yield and claw lesions can differ from that seen in older cows (Bielfeldt et al., 2005).

Most claw lesions develop around the time of calving. Hemorrhages, sole ulcers, and white-line fissures result from an insult to the corium that becomes visible on the bearing surface of the sole after 2 to $3 \mathrm{mo}$. We assessed milk yield in the same lactation as the claw trimming was performed, so any possible healing effect of claw trimming could have led to an underestimation of any negative effects of bad claw health on milk production. This effect was partly accounted for by including the variable that described whether the test day was before claw trimming, 1 mo after, or later. Several authors (Gröhn et al., 1995; Fleischer et al., 2001; Bielfeldt et al., 2005) analyzed milk yield in the previous lactation to avoid direct relationships between lameness and milk yield within the same lactation. RajalaSchultz et al. (1999) compared milk yield of cows with foot and leg disorders to their own yield more than 4 wk before the diagnosis. Further research is needed to evaluate if milk yield is also related to the timing of claw trimming during the lactation. Cows with low milk yield (Gröhn et al., 1995) and lameness and claw lesions are more likely to be culled (Sogstad et al., 2006). This is particularly problematic with lameness and claw lesions, because these disorders occur throughout the lactation (but usually around calving). Cows with high milk yield stay in the herd longer and have an increased chance of experiencing claw and limb disorders, thus 

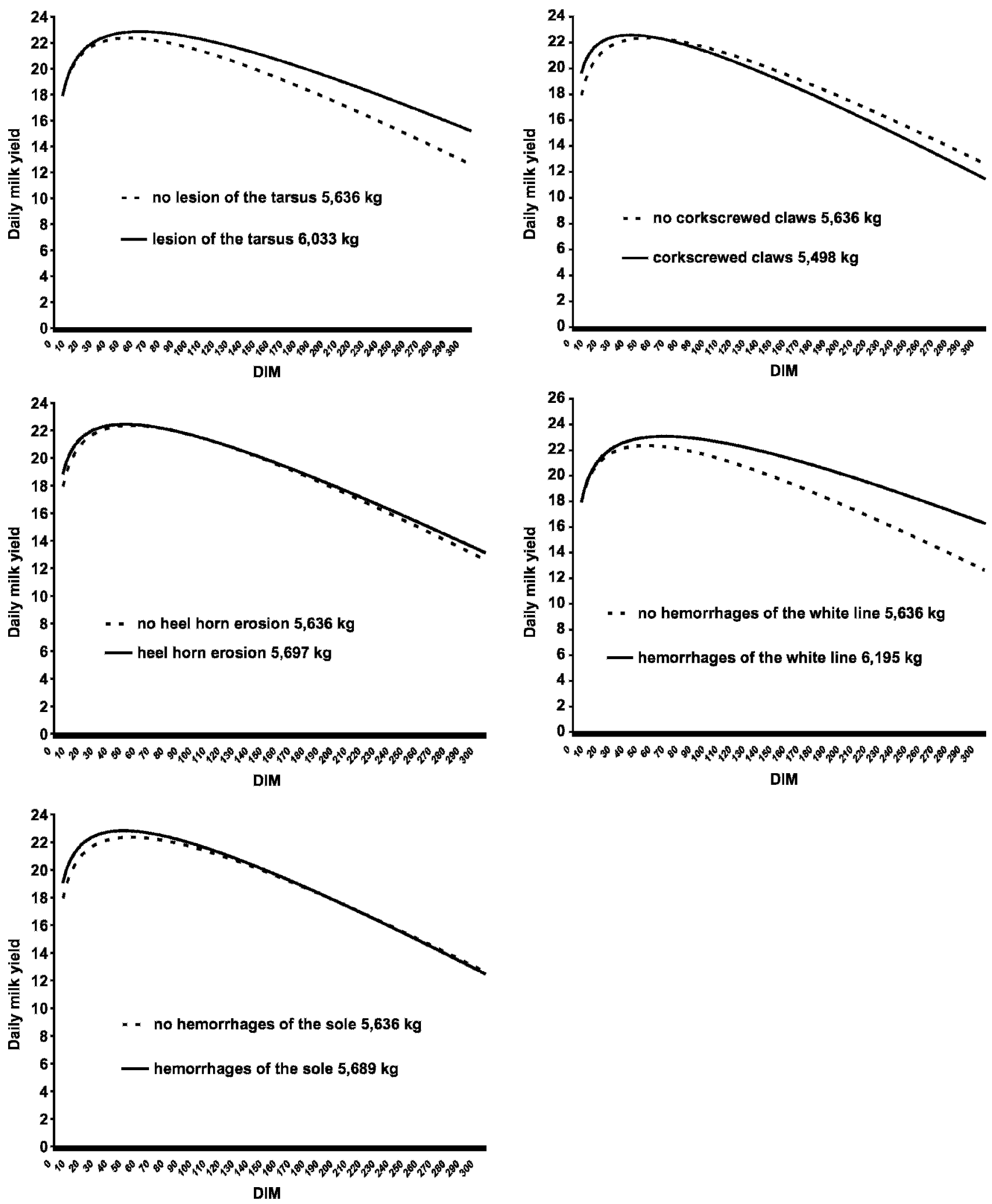

Figure 1. Lactation curves for cows in parity 1 with (- - ) or without (--- - ) lesions at the tarsus, corkscrewed claws, heel-horn erosions (score 0 vs. score 1, 2, and 3), and hemorrhages of the white line (score 1 and 2 vs. score 2 and 3 ) and the sole (score 0 vs. score 1,2 , and 3), adjusted to free-stall housing, test-day month May, test day before claw trimming, clinically healthy cow on test day, and no other lesion than the one in question at claw trimming. 

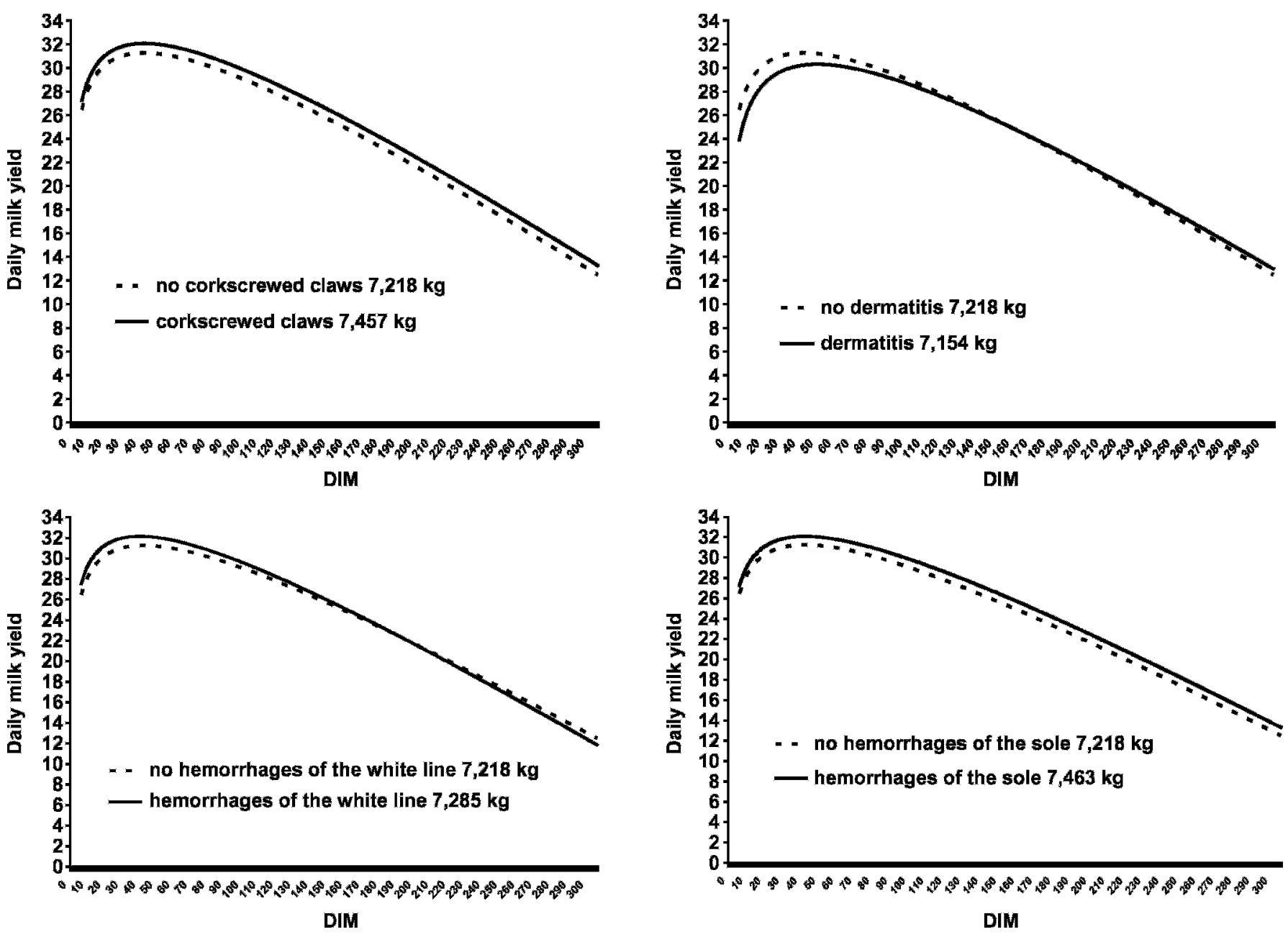

Figure 2. Lactation curves for cows in lactations $\geq 2$ with (-) or without (-- - - ) corkscrewed claws, dermatitis (score 0 vs. score 1 , 2 , and 3), and hemorrhages of the white line (score 1 and 2 vs. score 2 and 3) and the sole (score 1 and 2 vs. score 2 and 3 ), adjusted to free-stall housing, test-day month May, test day before claw trimming, clinically healthy cow on test day, and no other lesion than the one in question at claw trimming.

leading to an overestimation of the association between milk yield and such disorders.

The cluster effect within herd was significant for all hind claw lesions, but was most marked for heel-horn erosions in this study (Sogstad et al., 2005a). The cluster effect within claw trimmer was only significant for heel-horn erosions and is discussed in more detail in Sogstad et al. (2005a).

The prevalence of lameness and claw lesions in this study is discussed in Sogstad et al. (2005a). The prevalence of lameness was less than $2 \%$ and most claw lesions were score 1 . The clinical relevance of score 1 is not clear, although these lesions probably predispose for more serious lesions and lameness. The grouping of scores into dichotomous variables makes the models more robust due to more animals in each group. Because of a few cows in each class, it was expected that most lesions had to be dichotomized into 0 and 1 (scores 1,2 , and 3 ). This was the case, except for hemorrhages of the white line in lactation 1 , which were classified as 0 ( 0 and 1 ) and 1 (2 and 3 ).

Cows with painful claw lesions eat less, are more reluctant to move, and might consequently produce less milk than cows without claw lesions (Hassall et al., 1993). Reductions in milk yield associated with claw and limb disorders are likely to be caused by reductions in feed intake or increased energy consumption because of pain, which can also be present without visible lameness (Whay, 2002). It is, however, unlikely that claw lesions that are not painful lead to decreases in milk yield. The significant associations between most claw disorders and increased yield in this study do not prove direct relationships. Nutrition and feeding routines influence milk yield (Harstad, 1991a,b), and also develop- 

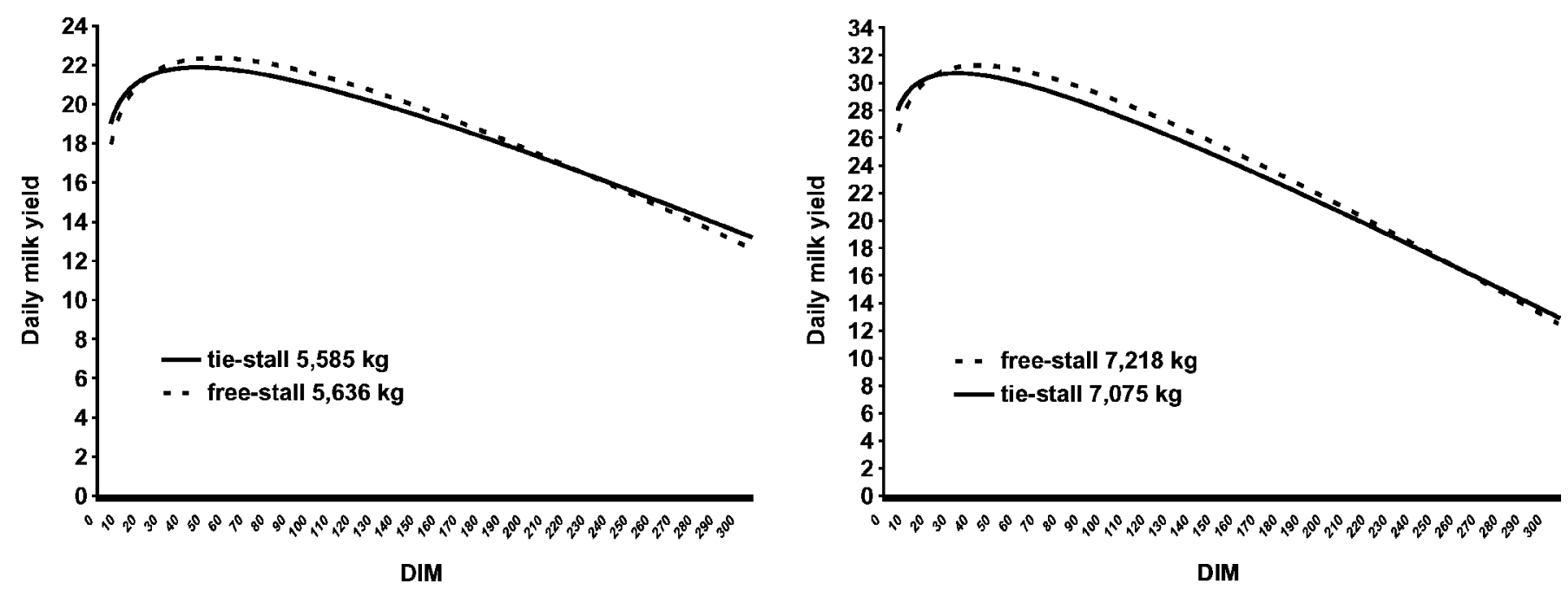

Figure 3. Lactation curves for reference cows in tie-stalls (-) and free-stalls (- - - - ) in parity 1 (left) and $\geq 2$ (right), adjusted to test-day month May, test day before claw trimming, clinically healthy cow on test day, and no other lesion than the one in question at claw trimming.

ment of claw lesions (Logue et al., 1993; Alban et al., 1996), by disturbing the microbial environment of the rumen (Harstad, 1991b). High milk yield has been associated with lameness and claw lesions by Alban et al. (1996) and Hultgren et al. (2004). Fjeldaas et al. (2006) found lower milk yield in Norwegian herds with a relative low prevalence of claw lesions and this might be because of differences in diets among herds. There was little variation in feeding intensity among study herds in our study (Sogstad et al., 2005a,b) and no significant effects when amount of concentrates was tested in the models, except for heel-horn erosions. Because of the complex influences of nutrition and DIM on production and claw health (rumen microbial flora, feces consistency, horn production, well being, and behavior), we did not include this variable.

\section{Claw and Limb Disorders}

Lameness reduces feed intake, live weight, milk yield, and milking duration (Margerison et al., 2004). Lameness was not associated with milk yield in our study, possibly because of the few recorded cases. Hernandez et al. (2005) indicated a linear relationship between increasing degree of lameness and decreasing milk yield among cows in second and later lactations. Aeberhard et al. (2001) found no differences in the incidence of claw and feet problems in high yielding vs. average-yielding cows and concluded that with adequate husbandry, management, and feeding, cows yielding $\geq 45 \mathrm{~kg} / \mathrm{d}$ can be maintained without more serious problems than cows yielding $35 \mathrm{~kg} / \mathrm{d}$. Coulon et al. (1996) found that milk production at the onset of foot lesions was a determining factor of the amount and pattern of milk loss, but only for cases in mid to late lactation.

The association between lesions at the tarsus and high milk yield for cows in lactation 1 might be explained by these animals being large and with long lying times on concrete stall bases. Heifers that calve late are often larger and have higher milk yield than others. An association between late first calving and white-line fissures was also found in our study (unpublished data).

Cows in lactation 1 with corkscrewed claws started off with higher milk yield than reference cows; however, milk yield decreased more rapidly. The decrease in milk yield in late lactation might be the result of pain caused by secondary claw lesions (Fjeldaas, 1983; Fjeldaas et al., 2006); however, in lactations 2 and above, cows with corkscrewed claws milked more throughout the lactation. Nutrition influences both milk yield (Aeberhard et al., 2001) and horn growth (van Amstel and Shearer, 2001) and could be the link between high milk yield and corkscrewed claws. There might also be a genetic correlation between high milk yield and corkscrewed claws. Further research is needed to verify this supposition.

There is no obvious explanation why cows with dermatitis in lactation 2 and above started off with a lower milk yield than other cows. The recorded cases of dermatitis in this study were assumed to be interdigital dermatitis (Sogstad et al., 2005a) and probably were not painful. Dermatitis and heel-horn erosions are correlated (Sogstad et al., 2005a). These lesions are infectious in origin and mainly influenced by the environ- 
Table 2. Significant estimates (b) and SE from the mixed models for variables associated with milk yield in parity 1 , with random effects of herd and individual

\begin{tabular}{|c|c|c|c|c|c|}
\hline Fixed variables ${ }^{1}$ & Class & $\begin{array}{l}\text { Lactations } \\
\text { (n) }\end{array}$ & $\begin{array}{l}\text { Test days } \\
\text { (n) }\end{array}$ & $\begin{array}{l}\text { Estimate } \\
\text { (b) }\end{array}$ & $\mathrm{SE}$ \\
\hline Intercept & & & 9,015 & $12.84 * * *$ & 1.72 \\
\hline DIM & & 1,013 & 9,015 & $-0.036^{* * *}$ & 0.0045 \\
\hline $\operatorname{lnDIM}$ & & 1,013 & 9,015 & $1.75^{* * *}$ & 0.35 \\
\hline \multirow[t]{2}{*}{ CORK } & 0 & 977 & 8,682 & $-3.12^{*}$ & 1.54 \\
\hline & 1 & 36 & 333 & 0 & - \\
\hline \multirow[t]{2}{*}{$\mathrm{E} 123^{2}$} & 0 & 766 & 6,810 & $-1.88 *$ & 0.82 \\
\hline & 1 & 247 & 2,205 & 0 & - \\
\hline \multirow[t]{2}{*}{$\mathrm{HS}_{123^{2}}$} & 0 & 807 & 7,233 & $-1.80 *$ & 0.70 \\
\hline & 1 & 206 & 1,782 & 0 & - \\
\hline \multirow{2}{*}{$\mathrm{DIM} \times \mathrm{TARS} 123^{3}$} & 0 & 975 & 8,681 & $-0.0085^{* * *}$ & 0.0023 \\
\hline & 1 & 38 & 334 & 0 & - \\
\hline \multirow[t]{2}{*}{$\mathrm{DIM} \times \mathrm{E} 123^{2}$} & 0 & 766 & 6,810 & $-0.0053^{*}$ & 0.0026 \\
\hline & 1 & 247 & 2,205 & 0 & - \\
\hline \multirow[t]{2}{*}{$\mathrm{DIM} \times \mathrm{HWL} 23^{2}$} & 0 & 1,001 & 8,888 & $-0.012^{* * * *}$ & 0.0035 \\
\hline & 1 & 12 & 127 & 0 & - \\
\hline \multirow[t]{2}{*}{$\mathrm{LnDIM} \times \mathrm{CORK}$} & 0 & 977 & 8,682 & $0.75^{*}$ & 0.31 \\
\hline & 1 & 36 & 333 & 0 & - \\
\hline \multirow[t]{2}{*}{$\mathrm{LnDIM} \times \mathrm{E} 123^{2}$} & 0 & 766 & 6,810 & $0.52 *$ & 0.23 \\
\hline & 1 & 247 & 2,205 & 0 & - \\
\hline \multirow[t]{2}{*}{$\mathrm{LnDIM} \times \mathrm{HS} 123^{2}$} & 0 & 807 & 7,233 & $0.34^{*}$ & 0.14 \\
\hline & 1 & 206 & 1,782 & 0 & - \\
\hline \multirow{3}{*}{ DIM_Ttrim } & -1 & 820 & 4,016 & $0.47^{* *}$ & 0.15 \\
\hline & 0 & 782 & 808 & $0.22 *$ & 0.11 \\
\hline & 1 & 844 & 4,191 & 0 & - \\
\hline \multirow[t]{2}{*}{ Stall type } & 1 & 439 & 3,885 & $2.86^{* * * *}$ & 0.77 \\
\hline & 2 & 574 & 5,130 & 0 & - \\
\hline \multirow[t]{2}{*}{ DIM $\times$ stall type } & 1 & 439 & 3,885 & $0.011 * * *$ & 0.0022 \\
\hline & 2 & 574 & 5,130 & 0 & - \\
\hline \multirow[t]{2}{*}{ LnDIM $\times$ stall type } & 1 & 439 & 3,885 & $0.10^{* * *}$ & 0.20 \\
\hline & 2 & 574 & 5,130 & 0 & - \\
\hline \multirow{2}{*}{ Diseased } & 0 & 1,012 & 9,000 & 4.96 *** & 0.55 \\
\hline & 1 & 15 & 15 & 0 & - \\
\hline \multirow[t]{12}{*}{ Test-day month } & January & 782 & 797 & $0.49 * * *$ & 0.098 \\
\hline & February & 768 & 783 & $0.57 * * *$ & 0.13 \\
\hline & March & 776 & 797 & $0.67 * * *$ & 0.15 \\
\hline & April & 772 & 800 & $0.95^{* * * *}$ & 0.16 \\
\hline & May & 793 & 853 & 1.30 *** & 0.17 \\
\hline & June & 694 & 708 & $1.10 * * *$ & 0.17 \\
\hline & July & 461 & 466 & $0.62 * * *$ & 0.18 \\
\hline & August & 692 & 717 & $0.48^{* *}$ & 0.16 \\
\hline & September & 743 & 772 & $0.46^{* *}$ & 0.15 \\
\hline & October & 737 & 772 & $-0.50 * * *$ & 0.13 \\
\hline & November & 716 & 754 & $-0.13^{0.2}$ & 0.098 \\
\hline & December & 742 & 796 & 0 & - \\
\hline Random effects & \multicolumn{2}{|r|}{$\mathrm{n}$} & \multicolumn{2}{|c|}{ Variance } & \\
\hline \multirow{3}{*}{$\begin{array}{l}\text { Herd } \\
\text { Lactations } \\
\text { Random error }\end{array}$} & \multirow{3}{*}{\multicolumn{2}{|c|}{$\begin{array}{r}110 \\
1,013\end{array}$}} & \multicolumn{2}{|c|}{2.84} & \\
\hline & & & \multicolumn{2}{|c|}{0.80} & \\
\hline & & & & & \\
\hline
\end{tabular}

\footnotetext{
${ }^{1}$ Variables: DIM = Test day in lactation (days after calving); TARS = lesion at tarsus; $\mathrm{CORC}=$ corkscrewed claws; $\mathrm{E}=$ heel-horn erosions; HWL = hemorrhages of the white line; $\mathrm{HS}=$ hemorrhages of the sole; DIM_Ttrim = days from trimming to milk test day $(0=$ the month after trim, $-1=>30 \mathrm{~d}$ after, $1=$ before); stall type $=$ tie-stall $(1)$ and free-stall $(2)$; Diseased $(0)=$ cow not diseased on test day, and diseased $(1)=$ cow diseased on test day; test-day month $=$ month of milk test day.

${ }^{2}$ Claw lesions: $0=$ absent, $1=$ mild, $2=$ moderate, $3=$ severe.

${ }^{3}$ Lesions at the tarsus: $0=$ absent, $1=$ swelling, $2=$ wound, $3=$ swelling and wound.

$* P<0.05 ; * * P<0.01 ; * * * P<0.001$.
}

ment (Philipot et al., 1993). Heel-horn erosions were also associated with milk yield; however, the model fit was better with dermatitis for cows in lactations 2 and above. Cows in lactation 1 with heel-horn erosions yielded $61 \mathrm{~kg}$ more than did reference cows. Intensive feeding results in wetter slurry. Enevoldsen et al. (1991b) found that high daily milk yield in first-lactation heifers was associated with a 1.5-fold higher risk 
Table 3. Significant estimates (b) and SE from the mixed models for variables associated with milk yield in parities $\geq 2$, with random effects of herd and individual

\begin{tabular}{|c|c|c|c|c|c|}
\hline Fixed variables $^{1}$ & Class & $\begin{array}{l}\text { Lactations } \\
\text { (n) }\end{array}$ & $\begin{array}{l}\text { Test days } \\
\text { (n) }\end{array}$ & $\begin{array}{l}\text { Estimate } \\
\text { (b) }\end{array}$ & $\mathrm{SE}$ \\
\hline Intercept & & & & $11.9 * * *$ & 1.5 \\
\hline DIM & & 1,586 & 13,417 & $-0.11 * * *$ & 0.0026 \\
\hline $\operatorname{lnDIM}$ & & 1,586 & 13,417 & $5.2 * * *$ & 0.27 \\
\hline \multirow[t]{2}{*}{ CORK } & 0 & 1,504 & 12,702 & $-0.80^{0.08}$ & 0.45 \\
\hline & 1 & 82 & 715 & 0 & - \\
\hline \multirow{2}{*}{$\mathrm{D} 123^{2}$} & 0 & 1,495 & 12,662 & $3.9 * * *$ & 1.2 \\
\hline & 1 & 91 & 755 & 0 & - \\
\hline \multirow[t]{2}{*}{ HWL123 ${ }^{2}$} & 0 & 1,423 & 12,044 & $-1.1213^{*}$ & 0.4625 \\
\hline & 1 & 163 & 1,373 & 0 & - \\
\hline \multirow[t]{2}{*}{$\mathrm{HS}_{123^{2}}$} & 0 & 1,362 & 11,495 & $-0.817^{* *}$ & 0.2968 \\
\hline & 1 & 224 & 1,922 & 0 & - \\
\hline \multirow[t]{2}{*}{$\mathrm{DIM} \times \mathrm{HWL} 123^{2}$} & 0 & 1,423 & 12,044 & $0.0058 * *$ & 0.0021 \\
\hline & 1 & 163 & 1,373 & 0 & - \\
\hline \multirow{2}{*}{ LnDIM D123² } & 0 & 1,495 & 12,662 & $-0.7761 * * *$ & 0.2348 \\
\hline & 1 & 91 & 755 & 0 & - \\
\hline \multirow[t]{3}{*}{ DIM_Ttrim } & -1 & 1,225 & 6,104 & $0.5134 * * *$ & 0.153 \\
\hline & 0 & 1,143 & 1,176 & $0.5206^{* * *}$ & 0.1097 \\
\hline & 1 & 1,297 & 6,137 & 0 & - \\
\hline \multirow[t]{2}{*}{$\mathrm{Knr}$} & 2 & 711 & 6,151 & $-0.483^{0.5}$ & 0.6351 \\
\hline & $>2$ & 875 & 7,266 & 0 & - \\
\hline \multirow[t]{2}{*}{$\mathrm{DIM} \times \mathrm{knr}$} & 2 & 711 & 6,151 & $0.01806^{* * *}$ & 0.002236 \\
\hline & $>2$ & 875 & 7,266 & 0 & - \\
\hline \multirow[t]{2}{*}{$\mathrm{LnDIM} \times \mathrm{knr}$} & 2 & 711 & 6,151 & $-0.8678 * * *$ & 0.1871 \\
\hline & $>2$ & 875 & 7,266 & 0 & - \\
\hline \multirow{2}{*}{ Stall type } & 1 & 661 & 5,535 & $4.2 * * *$ & 0.79 \\
\hline & 2 & 925 & 7,882 & 0 & - \\
\hline \multirow[t]{2}{*}{ DIM $\times$ stall type } & 1 & 661 & 5,535 & $0.01542^{* * *}$ & 0.0023 \\
\hline & 2 & 925 & 7,882 & 0 & - \\
\hline \multirow[t]{2}{*}{ LnDIM $\times$ stall type } & 1 & 661 & 5,535 & $-1.5^{* * * *}$ & 0.19 \\
\hline & 2 & 925 & 7,882 & 0 & - \\
\hline \multirow[t]{2}{*}{ Diseased } & 0 & 1,586 & 13,383 & $4.1^{* * *}$ & 0.48 \\
\hline & 1 & 32 & 34 & 0 & - \\
\hline \multirow[t]{12}{*}{ Test-day month } & January & 1,145 & 1,156 & $0.6305^{* * *}$ & 0.1011 \\
\hline & February & 1,102 & 1,114 & $0.7762 * * *$ & 0.1333 \\
\hline & March & 1,103 & 1,124 & $0.7442 * * *$ & 0.1512 \\
\hline & April & 1,161 & 1,205 & $1.0586 * * *$ & 0.1652 \\
\hline & May & 1,170 & 1,270 & $2.0447 * * *$ & 0.1736 \\
\hline & June & 1,069 & 1,105 & $1.973 * * *$ & 0.1767 \\
\hline & July & 753 & 772 & $1.5391 * * *$ & 0.1788 \\
\hline & August & 1,060 & 1,079 & $1.1937 * * *$ & 0.1622 \\
\hline & September & 1,105 & 1,137 & $1.0544 * * *$ & 0.1487 \\
\hline & October & 1,104 & 1,143 & $-0.00495^{0.97}$ & 0.1298 \\
\hline & November & 1,065 & 1,099 & $-0.2479^{*}$ & 0.1008 \\
\hline & December & 1,132 & 1,213 & 0 & - \\
\hline \multicolumn{2}{|l|}{ Random effects } & $\mathrm{n}$ & \multicolumn{2}{|c|}{ Variance } & \\
\hline \multirow{3}{*}{$\begin{array}{l}\text { Herd } \\
\text { Lactations } \\
\text { Random error }\end{array}$} & & 111 & \multicolumn{2}{|c|}{5.5} & \\
\hline & & 1,586 & \multicolumn{2}{|c|}{0.79} & \\
\hline & & 1,417 & & & \\
\hline
\end{tabular}

${ }^{1}$ Variables: DIM = test-day in lactation (days after calving); CORK = corkscrewed claws; D = dermatitis; HWL $=$ hemorrhages of the white line; HS = hemorrhages of the sole; DIM_Ttrim = time from trimming to milk test day; $(0=$ the month after trimming, $-1=>30 \mathrm{~d}$ after, $1=$ before $)$; $\mathrm{knr}=$ lactation number; stall type $=$ tie-stall $(1)$ and free-stall $(2)$; diseased $(0)=$ cow not diseased on test day, and diseased $(1)=$ cow diseased on test day; test-day month $=$ month of milk test day.

${ }^{2}$ Claw lesions: $0=$ absent, $1=$ mild, $2=$ moderate, $3=$ severe.

$* P<0.05 ; * * P<0.01 ; * * * P<0.001$.

of heel-horn erosions and explained this by more exposure to feces due to feces consistency. High milk production probably also forces the cow to spend more time eating. Heel-horn erosions in this study were correlated with hemorrhages of the white line and the sole (Sogstad et al., 2005a).

Cows with hemorrhages of the white line and the sole in lactations 1 and 2 and above had higher milk yield 
than cows without lesions. High milk yields require a certain amount of concentrates (Harstad, 1991a), and a high proportion of concentrates in the diet is a risk factor for hemorrhages (Logue et al., 1993). Hultgren et al. (2004) found associations between sole ulcer and $305-\mathrm{d}$ milk yield and 60 - to $180-\mathrm{d}$ milk yield (ECM) and explained this by high-producing cows being more prone to disease. Calcium is required for horn production (Mülling et al., 1999), and high milk yield might occur at the cost of normal horn production.

Sole ulcers and white-line fissures were not associated with milk yield in this study, possibly because of the few recorded cases.

\section{Milk Yield After Claw Trimming}

Increased milk yield after claw trimming can be the result of well being and more comfortable walking and standing after trimming to correct claw shape and positive effects on different disorders. By measuring different blood parameters, Nishimori et al. (2006) concluded that cows began to eat more roughage after claw trimming, but in contrast to our study they did not detect higher milk yields after claw trimming. Milk yield is expected to decrease with increasing number of DIM after peak yield. Test days after claw trimming are in a later stage of lactation than test days before trimming; however, this was accounted for by adjusting milk yield according to DIM.

\section{CONCLUSIONS}

Assessing the effect of claw and limb disorders on milk yield is not straightforward because of the complex influences of, for example, feeding routines and nutrition on both dependent and independent variables. In this study, in which most disorders were mild, the most evident results were higher milk yield in cows with lesions at the tarsus, heel-horn erosions, and hemorrhages of the white line and the sole than in other cows. This might be influenced by nutrition or the fact that cows with high milk yield are more prone to disorders. Low statistical power might have masked associations of lameness, sole ulcers, and white-line fissures. That cows yielded more milk after claw trimming than before is an economic incentive for routine claw trimming.

\section{ACKNOWLEDGMENTS}

The authors thank the participating claw trimmers and dairy farmers, Kerstin Plym Forshell, who was one of the main promoters in the planning stage of the study, and Ola Nafstad for his comments. The study was funded by TINE BA, GENO Breeding and A.I. Asso- ciation, Norwegian Meat Research Centre, and The Research Council of Norway. Access to production and health data was given by the Norwegian Dairy Herd Recording System and the Norwegian Cattle Health Services in agreement number 6/2001 by 19.09.2001.

\section{REFERENCES}

Aeberhard, K., R. M. Bruckmaier, U. Kuepfer, and J. W. Blum. 2001. Milk yield and composition, nutrition, body conformation traits, body condition scores, fertility and diseases in high-yielding dairy cows-Part 1. J. Vet. Med. 48:97-110.

Alban, L., J. F. Agger, and L. G. Lawson. 1996. Lameness in tied Danish dairy cattle: The possible influence of housing systems, management, milk yield, and prior incidents of lameness. Prev. Vet. Med. 29:135-149.

Bergsten, C. 2000. Workshop report about the documentation of claw diseases. Part 2. Pages 12-16 in Proc. 11th Int. Symp. Disorders of the Ruminant Digit. C. M. Mortellaro, L. Vecchis, A. De Brizzi, ed. Parma, Italy. Via A. Bianchi, Brescia, Italy.

Bielfeldt, J. C., R. Badertscher, K.-H. Tölle, and J. Krieter. 2005. Risk factors influencing lameness and claw disorders in dairy cows. Livest. Prod. Sci. 95:265-271.

Coulon, J. B., F. Lescourret, and A. Fonty. 1996. Effect of foot lesions on milk production by dairy cows. J. Dairy Sci. 79:44-49.

Enevoldsen, C., Y. T. Gröhn, and I. Thysen. 1991a. Sole ulcers in dairy cattle: Associations with season, cow characteristics, disease, and production. J. Dairy Sci. 74:1294-1298.

Enevoldsen, C., Y. T. Gröhn, and I. Thysen. 1991b. Heel erosion and other interdigital disorders in dairy cows: Associations with season, cow characteristics, disease and production. J. Dairy Sci. 74:1299-1309.

Enting, H., D. Kooij, A. A. Dijkhuizen, R. B. M. Huirne, and E. N. Noordhuizen-Stassen. 1997. Economic losses due to clinical lameness in dairy cattle. Livest. Prod. Sci. 49:259-267.

Fjeldaas, T. 1983. Klauv- og ekstremitetslidelser hos mjølkeku i relasjon til miljø. [Claw and leg disorders in dairy cows in relation to the environment]. MS Thesis. Norwegian School of Veterinary Science, Oslo. [In Norwegian]

Fjeldaas, T., A. M. Sogstad, and O. Østerås. 2006. Claw trimming routines in relation to claw lesions, claw shape and lameness in Norwegian dairy herds housed in tie stalls and free stalls. Prev. Vet. Med. 73:255-271.

Fleischer, P., M. Metzner, M. Beyerbach, M. Hoedemaker, and W. Klee. 2001. The relationship between milk yield and the incidence of some diseases in dairy cows. J. Dairy Sci. 84:2025-2035.

Fourichon, C., H. Seegers, N. Bareille, and F. Beaudeau. 1999. Effects of disease on milk production in the dairy cow: A review. J. Dairy Sci. 41:1-35.

Green, L., V. J. Hedges, Y. H. Schukken, R. W. Blowey, and A. J. Packington. 2002. The impact of clinical lameness on milk yield of dairy cows. J. Dairy Sci. 85:2250-2256.

Gröhn, Y. T., S. W. Eicker, and J. A. Hertl. 1995. The association between previous 305-day milk yield and disease in New York state dairy cows. J. Dairy Sci. 78:1693-1702.

Harstad, O. M. 1991a. Fôring av høgtytende mjølkeku [Feeding of high-yielding dairy cattle]. Del 1. Nor. Vet. Tidsskr. 10:899-912. [In Norwegian]

Harstad, O. M. 1991b. Fôring av høgtytende mjølkeku [Feeding of high-yielding dairy cattle]. Del 2. Nor. Vet. Tidsskr. 11:995-1007. [In Norwegian]

Hassall, S. A., W. R. Ward, and R. D. Murray. 1993. Effects of lameness on the behaviour of cows during the summer. Vet. Rec. 132:578-580.

Hernandez, J. A., E. J. Garbarino, J. K. Shearer, C. A. Risco, and W. W. Thatcher. 2005. Comparison of milk yield in dairy cows with different degrees of lameness. J. Am. Vet. Med. Assoc. 227:1292-1296.

Hultgren, J., T. Manske, and C. Bergsten. 2004. Associations of sole ulcer at claw trimming with reproductive performance, udder 
health, milk yield and culling in Swedish dairy cattle. Prev. Vet. Med. 62:233-251.

Kossaibati, M. A., and R. J. Esslemont. 1997. The costs of production diseases in dairy herds in England. Vet. J. 154:41-51.

Logue, D. N., J. Offer, and S. A. Kempson. 1993. Lameness in dairy cattle. Irish Vet. J. 46:47-58.

Macciotta, N. P. P., D. Vicario, and A. Cappio-Borlino. 2005. Detection of different shapes of lactation curve for milk yield in dairy cattle by empirical mathematical models. J. Dairy Sci. 88:1178-1191.

Macciotta, N. P., D. Vicario, C. Di Mauro, and A. Cappio-Borlino. 2004. A multivariate approach to modeling shapes of individual lactation curves in cattle. J. Dairy Sci. 87:1092-1098.

Margerison, J., J. Hollis, A. Snell, G. Stephens, and B. Winkler. 2004. The effect of lameness on feed intake, feeding behaviour, liveweight change, milk yield and milk let down and milking duration of Holstein Friesian dairy cattle. Page 38 in Proc. 13th Int. Symp. Lameness in Ruminants. B. Zemljic, ed. Maribor, Slovenia. Ungula, Zemljic \& Company, Ormoz, Slovenia.

Mülling, C. K., H. H. Bragulla, S. Reese, K. D. Budras, and W. Steinberg. 1999. How structures in bovine hoof epidermis are influenced by nutritional factors. Anat. Histol. Embryol. 28:103-108.

Nishimori, K., K. Okada, K. Ikuta, O. Aoki, T. Sakai, and J. Yasuda. 2006. The effects of one-time hoof trimming on blood biochemical composition, milk yield, and milk composition in dairy cows. J. Vet. Med. Sci. 68:267-270.

Østerås, O., L. Sølverød, and O. Reksen. 2006. Milk culture results in a large Norwegian survey-effect of season, parity, days in milk, resistance and clustering. J. Dairy Sci. 89:1010-1023.

Philipot, J. M., P. Pluvinage, I. Cimarosti, P. Sulpice, and F. Bugnard. 1993. Risk factors of dairy cow lameness associated with housing conditions. Int. Symp. Ecopathology Anim. Health Manag., Clermont Ferrand, France. 25:244-248.
Rajala-Schultz, P. J., Y. T. Gröhn, and C. E. McCulloch. 1999. Effects of milk fever, ketosis, and lameness on milk yield in dairy cows. J. Dairy Sci. 82:288-294.

Schaeffer, L. R., J. Jamrozik, G. J. Kistemaker, and B. J. Van Doormal. 2000. Experience with a test day model. J. Dairy Sci. 83:1135-1144.

Schukken, Y. H., K. E. Leslie, and A. J. Weersink. 1992. Ontario bulk milk somatic cell count reduction program. 1. Impact on somatic cell counts and milk quality. J. Dairy Sci. 75:3352-3358.

Sogstad, A. M., T. Fjeldaas, O. Østerås, and K. P. Forshell. 2005a. Prevalence of claw lesions in Norwegian dairy cattle housed in tie stalls and free stalls. Prev. Vet. Med. 70:191-209.

Sogstad, A. M., T. Fjeldaas, and O. Østerås. 2005b. Lameness and claw lesions of the Norwegian Red dairy cattle housed in free stalls in relation to environment, parity and stage of lactation. Acta Vet. Scand. 4:203-217.

Sogstad, A. M., O. Østerås, and T. Fjeldaas. 2006. Bovine claw and limb disorders related to reproductive performance and production diseases. J. Dairy Sci. 89:2519-2528.

Sogstad, A. M., O. Østerås, T. Fjeldaas, and O. Nafstad. 2006. Bovine claw and limb disorders related to culling and carcass characteristics. Livest. Sci. doi:10.1016/j.livsci.2006.07.003

van Amstel, S. R., and J. K. Shearer. 2001. Abnormalities of hoof growth and development. Vet. Clin. North Am. Food Anim. Pract. 17:73-91.

Warnick, L. D., D. Janssen, C. L. Guard, and Y. T. Gröhn. 2001. The effect of lameness on milk production in dairy cows. J. Dairy Sci. 84:1988-1997.

Whay, H. R. 2002. A review of current pain management in ruminants-The lame cow model. Pages 131-138 in Proc. 12th Int. Symp. Lameness in Ruminants. J. K. Shearer, ed. Orlando, FL.

Wilmink, J. B. M. 1987. Adjustment of test day milk, fat and protein yield for age, season and stage of lactation. Livest. Prod. Sci. 16:335-348.

Wood, P. D. P. 1967. Algebraic model of the lactation curve in cattle. Nature 216:164-165. 